\title{
KINERJA SISTEM CHAOTIC DIGITAL CDMA DENGAN MODULASI QUADRATURE CHAOTIC SHIFT KEYING
}

\author{
Asep Permadi ${ }^{1}$, Hadi Suwastio ${ }^{2}$, Suyatno $^{3}$ \\ ${ }^{1,2}$ Jurusan Teknik Elektro STT Telkom Bandung \\ 2hso@stttelkom.ac.id
}

\begin{abstract}
Abstrak
Salah satu definisi chaos adalah "sebuah keteraturan tanpa periodisitas"[10]. Salah satu sifat dari chaos adalah unpredictable atau tidak dapat di prediksi. Salah satu dari aplikasi chaos ini adalah digunakannya sinyal chaos pada teknik spreading code pada CDMA. Dengan teknik ini diharapkan tingkat keamanan dari sinyal informasi yang di tebar menjadi lebih tinggi. Teknik spreading code dengan menggunakan chaos ini sering disebut (CD) ${ }^{2}$ MA atau Chaotic Digital Code Divission Multiple Access. Penelitian yang sudah dilakukan adalah teknik $(\mathrm{CD})^{2} \mathrm{MA}$ dan dimodulasikan dengan menggunakan teknik modulasi VMSK (Very Minimum Phase Shift-Keying) yang mempunyai efisiensi bandwidth cukup efektif, namun proses demodulasinya sangat sulit sebab harus mengunakan filter kristal dengan delay group yang besar. Penelitian ini akan mencoba menggabungkan sistem (CD) ${ }^{2}$ MA dan memodulasikannya dengan QCSK (Quadrature Chaotic Shift Keying). Dasar pemikiran QCSK adalah modulasi QPSK yang mempunyai performansi hampir sama dengan BPSK tetapi mempunyai efisiensi BW yang lebih baik. QCSK mempunyai efisiensi Bandwidth yang lebih baik yaitu setengah dari sistem DCSK. Hal ini diharapkan dapat mengimbangi sistem $(\mathrm{CD})^{2} \mathrm{MA}$ yang menghasilkan lebar bandwidth yang cukup lebar.Hasil yang diharapkan adalah performansi dan efisiensi bandwidth sistem lebih baik atau sama dengan performansi yang dihasilkan dari sistem $(\mathrm{CD})^{2}$ MA yang dimodulasikan dengan modulasi VMSK.
\end{abstract}

Kata kunci: Chaos, (CD) ${ }^{2}$ MA, QCSK, VMSK, MAI, Processing Gain

Abstract

Chaos can be defined as "regularity without periodicity" [10]. One of chaos properties is unpredictable. One of chaos applications is the usage of chaos as a spreading code in CDMA. Using this technique, the security of the information-spread signal is higher. The system using chaos spreading code is called $(\mathrm{CD})^{2} \mathrm{MA}$ or Chaotic Digital Code Divission Multiple Access. The research of (CD) $)^{2} \mathrm{MA}$ that has been done, uses VMSK (Very Minimum Phase Shift-Keying) modulation. This modulation has high bandwidth efficiency but the demodulation is difficult because it has to use a chrystall filter with large group delay. In this research, the combination of of $(\mathrm{CD})^{2} \mathrm{MA}$ and QCSK (Quadrature Chaotic Shift-Keying) modulation is performed. The basic idea of QCSK is the performance of QPSK is almost the same with BPSK but with a better bandwidth efficiency. The QCSK has higher bandwidth efficiency (50\%) compared with DCSK. This is to compensate the (CD) ${ }^{2} \mathrm{MA}$ which produces a large bandwidth signal. The expected result is the performance and the bandwidth efficiency are better or the same as the combination of $(\mathrm{CD})^{2} \mathrm{MA}$ and VMSK modulation.

Keywords: Chaos, (CD)²MA, QCSK, VMSK, MAI, Processing Gain

1. Pendahuluan

Pada sistem komunikasi spread spectrum, pengirim melakukan penebaran sinyal informasi dengan menggunakan sinyal penebar berupa deretan kode acak dengan laju bit lebih besar dari laju bit sinyal data itu sendiri. Deretan kode acak tersebut, selain digunakan sebagai penebar, juga berfungsi sebagai alat untuk membedakan sinyal-sinyal datang dari masing-masing pengguna yang ditransmisikan dalam waktu dan frekuensi sama.

Sistem Chaostic Digital Code Divission Multiple Access atau (CD) ${ }^{2} \mathrm{MA}$ adalah sistem $D S$ CDMA (Direct Sequence CDMA) dengan sinyal Chaos sebagai spreader[1]. Sinyal chaos bersifat unpredictable, sehingga diharapkan memberikan keamanan pada transmisi sinyal dan diharapkan juga dapat mengelimininasi efek multiuser interference dalam sistem komunikasi multiuser[1].

Sinyal chaos yang digunakan sebagai sinyal carrier pada sistem modulasi sudah banyak dikembangkan, seperti: Chaotic Masking[9], Predictive Poincare Control[9], CSK (Chaos Shift keying)[7], dan DCSK (Diferential Chaos Shift Keying)[8]. Penelitian ini mengembangkan model sistem modulasi QCSK (Quadrature Chaos Shift Keying)[3]. Modulasi QCSK didasari oleh modulasi QPSK yang mengkodekan 2 bit informasi pada 1 simbol. Karena bandwidth sistem dapat ditekan sampai setengahnya, maka sistem (CD) ${ }^{2} \mathrm{MA}$ diharapkan merupakan sistem spread sprectrum yang mempunyai bandwith cukup efisien. 


\section{Konsep Dasar CDMA, Modulasi Quadrature, dan Fenomena Chaos}

Sistem komunikasi spread spectrum secara umum dibagi dua yakni DS-SS (Direct Sequence Spread Spectrum) dan FH-SS (Frequency Hopping Spread Spectrum). Pada sistem DS-SS sinyal informasi ditebar menjadi sinyal yang memiliki spektrum frekuensi yang jauh lebih lebar dibanding spektrum sinyal aslinya dengan sebuah kode bit penebar yang tidak tergantung pada sinyal informasi. Sedangkan pada FH-SS, pada saat pengiriman sinyal informasi, sinyal informasi tersebut akan dilompatlompatkan pada beberapa frekuensi pada range tertentu di mana range tersebut jauh lebih lebar dari pada spektrum frekuensi sinyal informasi aslinya, dan pola lompatan dari sinyal informasi ini akan didasarkan pada sebuah kode penebar random yang tidak tergantung pada sinyal informasi.

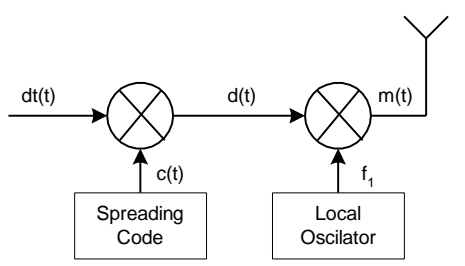

(a) Pengirim

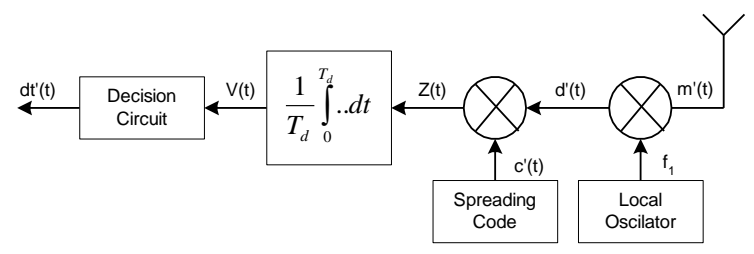

(b) Penerima

Gambar 1. Diagram Blok Sistem DS-SS

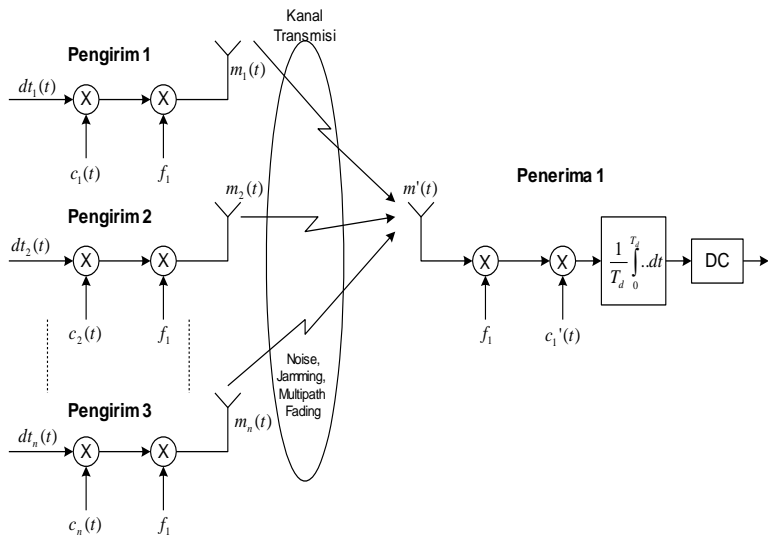

Gambar 2. Diagram Blok Pemodelan Sistem CDMA

\subsection{Sistem DS-SS dan CDMA}

Pemodelan sistem DS-SS (Direct-Sequence Spread-Spectrum) dijelaskan dalam blok diagram pengirim dan penerima seperti pada Gambar 1. Pada sisi pengirim, sinyal data $\mathrm{dt}(\mathrm{t})$ dengan bit rate $\mathrm{R}_{\mathrm{d}}$ akan di spread ke dalam lebar frekuensi yang jauh lebih lebar dari sinyal aslinya dengan mengunakan sebuah kode penebar acak dengan chip rate $R_{c}$, dimana $R_{c} \gg R_{d}$. Sinyal yang diterima di receiver adalah sinyal termodulasi yang telah teredam oleh kanal sebesar $\alpha$ dan juga telah mengalami delay selama $\tau$, maka sinyal yang diterima oleh receiver dapat dimodelkan sebagai:

$$
m^{\prime}(t)=\alpha \cdot d t(t-\tau) \cdot c^{\prime}(t-\tau) \cdot \cos \left(2 \cdot \pi \cdot f_{1}(t-\tau)\right)
$$

Konsep sistem DS-CDMA yang merupakan pengembangan dari sistem DS-SS diperlihatkan dalam diagram blok pada Gambar 2.

\subsection{Modulasi Quadrature}

QCSK merupakan jenis modulasi digital yang mengekploitasi sinyal chaos sebagai basis sinyal pemodulasinya. Modulasi QCSK adalah modulasi quadrature dimana bit informasi akan dikirimkan per simbol dan setiap simbol terdiri dari 2 (dua) bit informasi. Modulasi QCSK adalah pengembangan dari skema modulasi DCSK (Differential Chaos Shift Keying). Pada modulasi DCSK satu simbol terdiri dari satu bit informasi. Tujuan awal digunakannya teknik quadrature pada modulasi berbasis sinyal chaos adalah untuk meningkatkan data rate transmisi. Dengan dikirimkannya 2 (dua) bit informasi sekaligus berarti data rate akan naik dua kalinya.

Jika modulasi QCSK ini dipandang sebagai teknik modulasi sinyal sinusoidal, maka QCSK dapat disepandankan dengan modulasi QPSK (Quadrature Phase Shift Keying), sedangkan DCSK dapat disepadankan dengan modulasi BPSK (Binary Phase Shift Keying). Sistem QPSK dan BPSK memiliki kinerja BER (Bit Error Rate) yang sama, namun QPSK memiliki data rate dua kali lebih cepat dari pada BPSK.

\subsection{Fenomena Chaos}

Menurut Shilnikov, chaos adalah perilaku dinamis yang mempunyai suatu himpunan yang unik dan invarian. Sedangkan menurut Chirtopher Silva, chaos adalah suatu sistem dinamis yang mempunyai perilaku terbatas yang menghasilkan beberapa ciri dasar, tiga di antaranya adalah:

1. Spektrum daya yang kontinyu pada suatu pita frekwensi tertentu. Ciri ini menunjukkan sinyal yang nonperiodik dan sekaligus menjadikan chaos sering dianalogikan dengan sinyal noise.

2. Mempunyai kepekaan yang tinggi terhadap kondisi awal.

3. Ergodik pada suatu sample space terbatas

\subsection{Pemodelan Kanal}

Penjalaran sinyal dari pengirim menuju penerima dalam sistem komunikasi wireless, akan mengalami berbagai pantulan, redaman, penguatan, difraksi dan lain-lain. Sehingga penerima akan menerima sinyal hasil penjumlahan dari berbagai 
lintasan yang telah mengalami peredaman, penguatan, difraksi dan lain-lain, sehingga sinyal terima tersebut telah mengalami variasi amplituda dan fasa yang acak sepanjang perioda waktu yang cukup singkat, sehingga sinyal yang diterima adalah sinyal yang telah mengalami distorsi akibat efek kanal atau biasa disebut small-scale fading. Faktor yang mempengaruhi terjadinya small-scale fading di antaranya: multipath propagation, kecepatan penerima, kecepatan objek, dan bandwidth sinyal yang dikirim. Yang banyak digunakan untuk mensimulasikan model kanal dalam sistem komunikasi wireless adalah model kanal yang terganggu oleh multipath fading yang terdistribusi Rayleigh dan oleh noise.

Sinyal yang diterima di receiver adalah sinyal yang telah mengalami distorsi akibat efek kanal atau small-scale fading.

Noise terdistribusi Gaussian, atau sering disebut dengan Aditive White Gaussian Noise (AWGN), memiliki karakteristik statistik sesuai Probability Density Function (PDF) Gaussian yang dapat dituliskan sebagai berikut:

$$
p(n)=\frac{1}{\sigma \sqrt{2 \pi}} \cdot \exp \left[-\frac{1}{2}\left(\frac{n}{\sigma}\right)^{2}\right]
$$

dengan $\sigma^{2}$ adalah varians dari $n$. Probability Density Function (PDF) noise Gaussian yang ternormalisasi (normalized or standardized Gaussian density function) dengan proses zero-mean dapat dicari dengan mengasumsikan $\sigma=1$.

\section{Model Sistem (CD)2MA dan Modulasi QCSK}

Sistem (CD) $)^{2} \mathrm{MA}$ (Chaotic Digital Code Division Multiple Access) merupakan sistem komunikasi spektral tersebar (spread spectrum) yang mengeksploitasi sinyal chaos sebagai basis pembangkitan kode penebar acaknya. Skema sistem (CD) ${ }^{2}$ MA hampir sama dengan sistem komunikasi spektral tersebar DS-CDMA dengan pseudo-random generator (PRG) berupa suatu generator chaos digital, sebagaimana diperlihatkan pada Gambar 3.

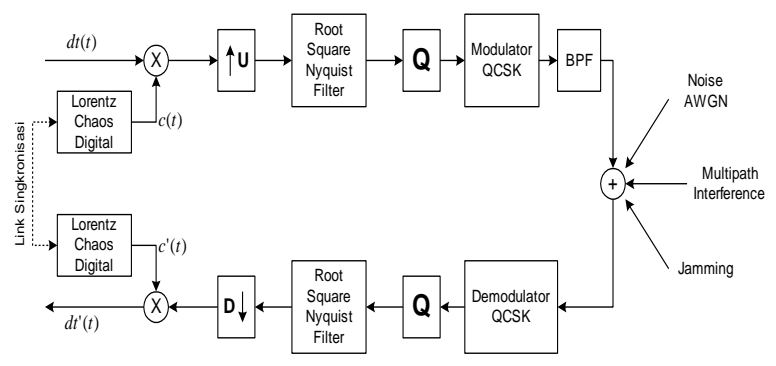

Gambar 3. Diagram Blok Sistem (CD) ${ }^{2} \mathrm{MA}$

\subsection{Modulasi Berbasis Sinyal Chaos}

Salah satu skema yang mempunyai keandalan dalam sistem transmisi misalnya adalah DCSK (Differential Chaos Shift Keying) yang mempunyai performansi BER (Bit Error Rate) cukup baik. Skema ini digunakan untuk memodulasi sinyal digital, dimana skema tersebut memberikan performansi yang lebih baik dari skema modulasi konvensional yang mengunakan sinyal sinusoidal sebagai pembawanya.

\subsection{Sinyal Chaos yang saling Orthogonal}

Hal yang terpenting dari skema modulasi QCSK adalah cara mendapatkan sinyal chaos lain yang saling orthogonal jika diberikan suatu sinyal chaos pada interval tertentu. Misalnya dua buah sinyal chaos $C_{1}(t)$ dan $C_{2}(t)$, keduanya dapat digunakan untuk memodulasi data informasi jika antar-kedua sinyal tersebut memiliki karakteristik saling orthogonal, yaitu dalam selang interval tertentu $[0, \tau]$ dapat memenuhi syarat:

$$
\int_{0}^{\tau} C_{1}(t) C_{2}(t) \approx 0
$$

\subsection{Hilbert Transform Waktu Diskrit}

Secara umum Hilbert transfo(2n 2Q) nghasilkan pergeseran fasa dari sinyal masukan sejauh $\pi / 2$ untuk setiap komponen frekuensinya. Pada penelitian ini akan dilakukan Hilbert transform dari sinyal dalam kawasan frekuensi, oleh karena itu sebelum sebuah sinyal dilewatkan pada blok Hilbert transform, maka sinyal tersebut dilewatkan dulu pada blok FFT (Fast Fourier Transform). Hilbert transform yang digunakan dalam penelitian ini ditujukan untuk menghasilkan sinyal yang saling orthogonal, seperti diperlihatkan pada Gambar 4.

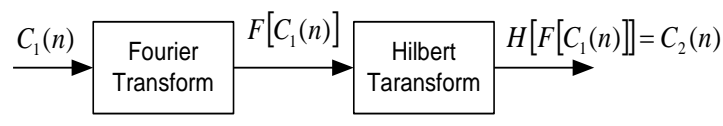

\section{Gambar 4. Diagram Blok Hilbert Transform}

Persamaan Hilbert transform waktu diskrit dapat didefinisikan sebagai berikut:

$$
h(n)=\frac{2}{N} \sum_{k=1}^{\frac{N}{2}-1} \sin \left(\frac{2 \pi}{N} k n\right)
$$

untuk $N=$ jumlah sample diskrit genap, atau:

$$
h(n)=\frac{2}{N} \sum_{k=1}^{\frac{N-1}{2}} \sin \left(\frac{2 \pi}{N} k n\right)
$$

untuk $N=$ jumlah sample diskrit ganjil.

\subsection{Quadrature Chaos Shift Keying (QCSK)}

Modulasi QCSK (Quadrature Chaos Shift Keying) yang mengeksploitasi sinyal chaos sebagai basis modulasinya dijelaskan dengan diagram blok pada Gambar 5. 


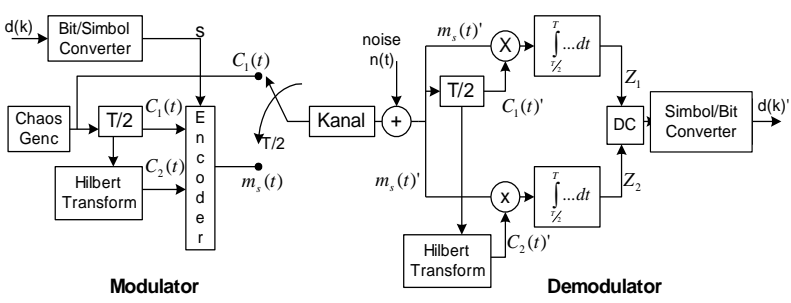

Gambar.5. Diagram blok sistem modulasi QCSK

\section{Analisis Sistem (CD) ${ }^{2}$ MA dan Modulasi QCSK}

Pada Gambar 6 diperlihatkan lintasan sinyal chaos, dengan attractor dan proyeksi setiap state terhadap state lainnya berasal dari dua nilai kondisi awal yang dibedakan sebesar $0.00001 \%$.

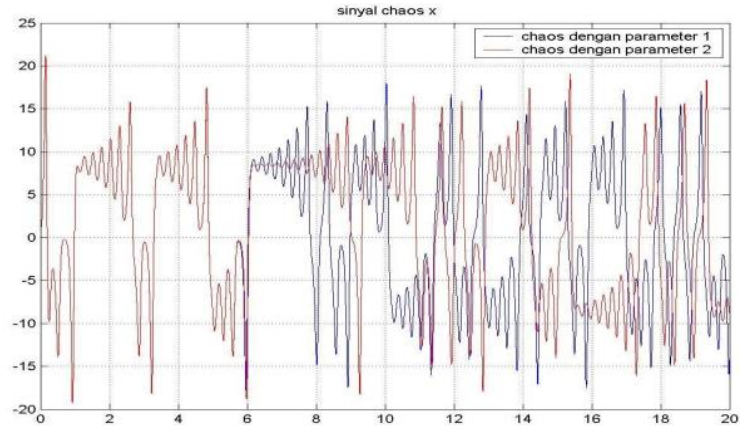

Gambar 6. Sinyal Chaos Lorenz untuk State Variable " $x$ "

Parameter yang diberikan untuk menggambarkan kedua lintasan sinyal chaos tersebut dapat dilihat pada Tabel 1

Tabel 1. Berbagai Nilai Parameter untuk 2 Jenis Sinyal Chaos

\begin{tabular}{|c|c|c|}
\hline Parameter & $\begin{array}{c}\text { Nilai Parameter } \\
\text { Sinyal Chaos-1 }\end{array}$ & $\begin{array}{c}\text { Nilai Parameter } \\
\text { Sinyal Chaos-2 }\end{array}$ \\
\hline Initial Condition: & 1 & \\
$x_{0}$ & 1 & 1 \\
$y_{0}$ & 1 & 1 \\
$z_{0}$ & 10 & 10 \\
\hline$S$ (sigma) & 28 & 28 \\
\hline$R$ & $8 / 3$ & $8 / 3$ \\
\hline$B$ & & \\
\hline
\end{tabular}

\subsection{Randomness}

Hasil uji randomness dari sinyal generator chaos yang digunakan dalam simulasi ini diperlihatkan pada Tabel 2.

\subsection{Power Spectral Density}

Sinyal chaos memiliki sifat dimana spektral dayanya kontinyu dalam range frekuensi yang sangat lebar, sehingga sinyal chaos ini sering di analogikan sebagai sinyal noise. Pada Gambar 7 diperlihatkan bentuk-bentuk sinyal chaos untuk setiap state variabelnya dan spektral dayanya.
Tabel 2. Hasil Test Randomness untuk Berbagai Kondisi Awal

\begin{tabular}{|c|c|c|c|}
\hline \multicolumn{3}{|c|}{ Parameter Generator Chaos } & $\begin{array}{c}\text { Hasil Test } \\
\text { Randomness } \\
\text { Initial Condition }\end{array}$ \\
\cline { 1 - 3 } $\boldsymbol{z}_{\mathbf{0}}$ & $\boldsymbol{y}_{\mathbf{0}}$ & $\boldsymbol{z}_{\mathbf{0}}$ & 1.4325 \\
\hline 0.1 & 0.1 & 0.1 & -0.5372 \\
\hline 5 & 5 & 5.45351 & 0.5372 \\
\hline 2 & 2 & 2.2965435 & 1.1639 \\
\hline 3 & 3 & 3.2965435 & 0.4477 \\
\hline 7.57635 & 8 & 2 & 1.3430 \\
\hline 6.53456 & 3 & 2 & -1.0592 \\
\hline 1.53456 & 3 & 1 & 1.3430 \\
\hline 0.53456 & 6 & 9 & -0.5372 \\
\hline 1 & 9.674 & 2.3423 & 0.2686 \\
\hline 5 & 2.674 & 6.3423 & \\
\hline
\end{tabular}
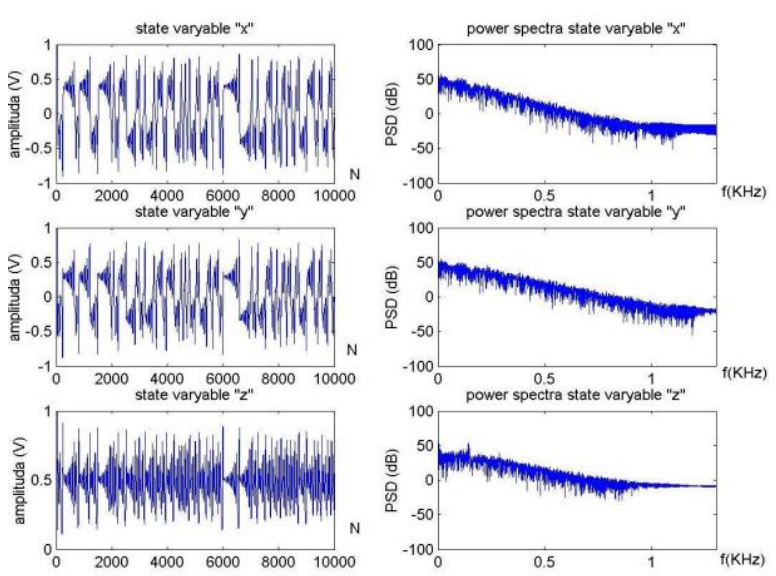

Gambar 7. Sinyal Chaos untuk Setiap State Variabelnya dan Spektral Dayanya

\subsection{Ergodicity}

Suatu sistem waktu diskrit dikatakan ergodic jika dan hanya jika memenuhi dua syarat, yaitu:

1). Rataan Statistik = Rataan Waktu, dan

2). Rataan Statistik Auto-korelasi = Ratan Waktu

Auto-korelasi

Proses $x(t)$ adalah ergodic jika auto-kovariannya $C\left(t_{1}, t_{2}\right)$ sedemikian hingga $\sigma_{T}^{2} \rightarrow 0$ untuk $T \rightarrow \infty$. Gambar 8 menunjukan hasil simulasi grafik autokovarians yang memiliki nilai varian terus mengecil dan menuju nol pada titik $N \rightarrow \infty$.

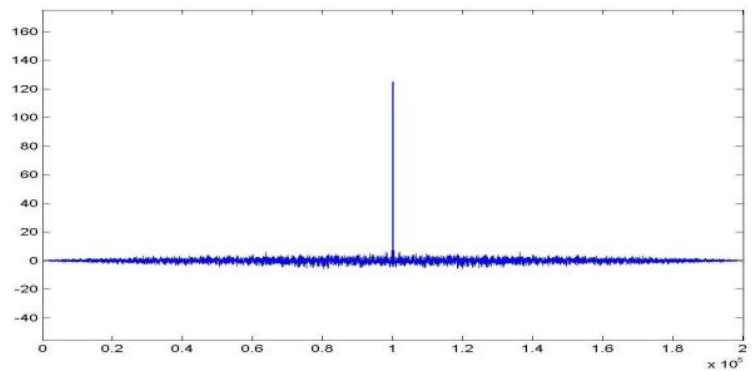

Gambar 8. Grafik Auto-kovarians

Auto-korelasi adalah karakteristik yang menyatakan keterkaitan antara sampel sinyal ke- $n$ dengan sampel sinyal sebelum dan sesudahnya. Gambar 9 memperlihatkan bentuk sifat auto-korelasi sinyal chaos ternormalisasi untuk setiap state variablenya. 


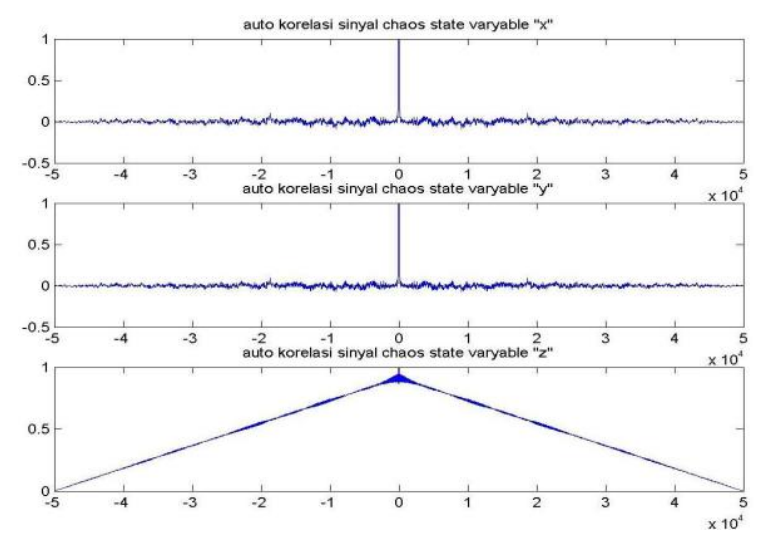

Gambar 9. Auto-korelasi Sinyal Chaos Ternormalisasi

\subsection{Kinerja Sistem Tanpa Gangguan Kanal}

Berikut ini dilakukan percobaan dengan mengirimkan sebanyak 50 bit data acak yang terdistribusi uniform dengan bit rate $50 \mathrm{kbps}$, kemudian sinyal tersebut dimodulasikan dan didemodulasikan tanpa ada gangguan kanal. Hasil percobaan tersebut diperlihatkan pada Gambar 10, yang menunjukkan bahwa model sistem modulasidemodulasi QCSK telah bekerja dengan benar.

Kinerja sistem dievaluasi berdasarkan BER (Bit Error Rate), yaitu perbandingan antara jumlah bit yang salah dibandingkan dengan jumlah bit keseluruhan yang dikirim.

$$
B E R=\frac{\text { jumlah bit salah pada penerima }}{\text { jumlah bit masukan pada penginim }}
$$
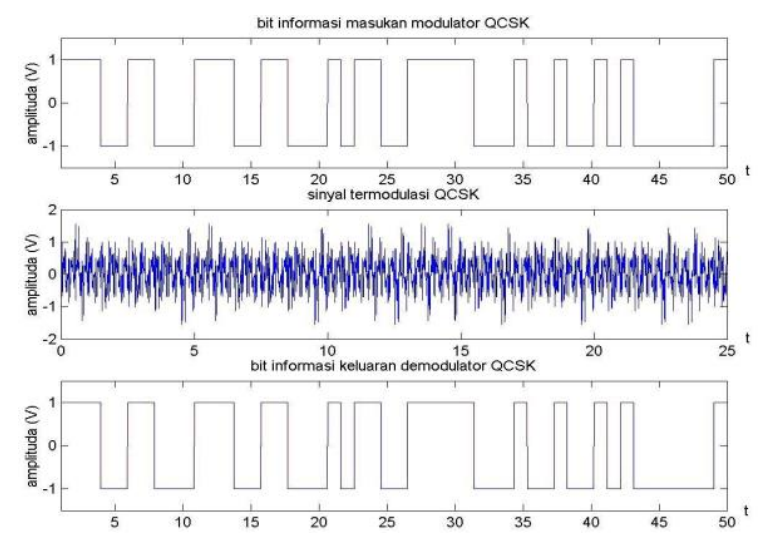

Gambar 10. Sinyal Data, Sinyal Modulasi, dan Sinyal Hasil Demodulasi

Tabel 3. BER vs Jumlah Bit Terkirim

\begin{tabular}{|l|c|c|c|c|c|c|}
\hline Jumlah Bit & 100 & 500 & 1000 & 2000 & 5000 & 10000 \\
\hline BER & 0 & 0 & 0 & 0 & 0 & 0 \\
\hline
\end{tabular}

Untuk memberikan verifikasi model sistem yang lebih valid, dilakukan percobaan lagi untuk pengiriman data lebih besar, sehingga benar-benar dapat dibuktikan model sistem yang dirancang telah bekerja baik. Tabel 3 menunjukan tidak adanya bit salah pada pengiriman berbagai jumlah bit data, sebelum diberikan gangguan kanal.

\subsection{Kinerja Sistem pada Beberapa Model Kanal}

Gambar 11 memperlihatkan kinerja sistem pada model kanal AWGN dan tiga macam model kanal fading yang direpresentasikan oleh perubahan nilai BER (Bit Error Rate) terhadap perubahan $S / N$.

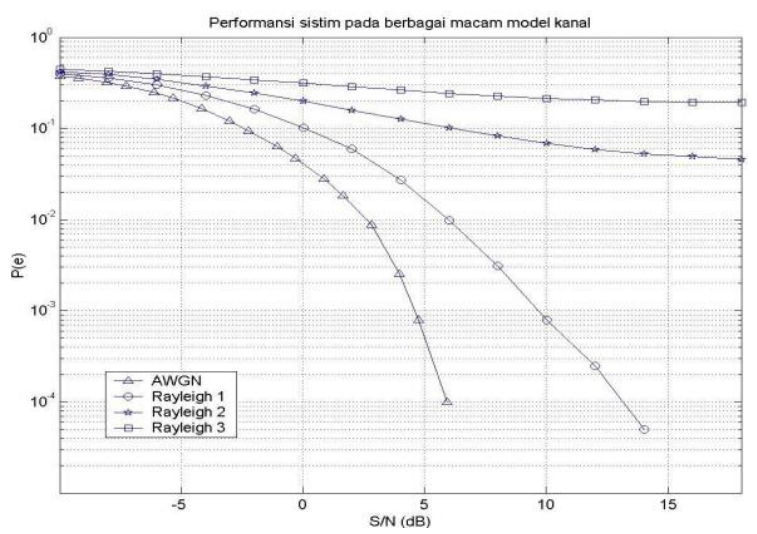

Gambar 11. Grafik BER vs $S / N$

Adapun penjelasan model kanal fading yang digunakan adalah kanal yang terganggu oleh noise AWGN dan terganggu oleh multipath Rayleigh fading, dengan spesifikasi sebagai berikut:

1. Rayleigh-1

- Frekuensi Doppler sebesar $60 \mathrm{~Hz}$.

- Tidak diberikan sinyal multipath, direalisasikan dengan model kanal single ray, sehingga memberikan efek flat Rayleih fading.

2. Rayleigh-2

- Delay spread sebesar $3 \mu$ s.

- Frekuensi Doppler sebesar $60 \mathrm{~Hz}$.

3. Rayleigh-3

- Delay spread sebesar $0.3 \mu$ s.

- Frekuensi Doppler sebesar $60 \mathrm{~Hz}$.

\subsection{Perbandingan Kinerja Sistem $(\mathrm{CD})^{2} \mathrm{MA}$ dengan Modulasi QCSK dan VMSK}

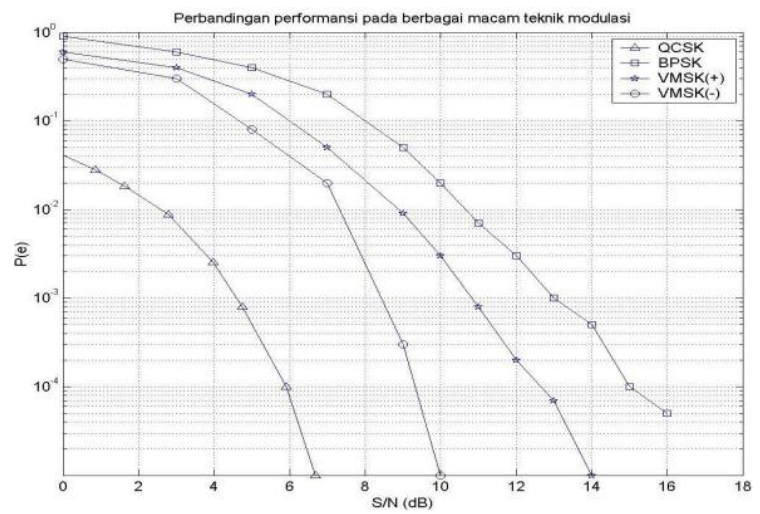

Gambar 12. Grafik Kinerja Sistem (CD) ${ }^{2}$ MA dengan Berbagai Teknik Modulasi pada Kanal AWGN

Pada penelitian lain yang dilakukan sebelum penelitian ini, diteliti mengenai sistem $(\mathrm{CD})^{2} \mathrm{MA}$ yang didukungkan oleh sistem modulasi VMSK (Very Minimum Phase Shift Keying). Gambar 12 
memperlihatkan kinerja sistem $(\mathrm{CD})^{2} \mathrm{MA}$ pada kanal AWGN yang didukung oleh berbagai macam teknik modulasi.

\subsection{Multiple Access Interference (MAI)}

Seperti telah dijelaskan pada sub-bab 3.2, konstribusi adanya gangguan MAI (Multiple Access Interference) pada sistem komunikasi spektral tersebar akan sangat ditentukan oleh nilai korelasi antara sinyal penebar yang satu dengan yang lainya. MAI dapat dimodelkan seperti gambar 13.

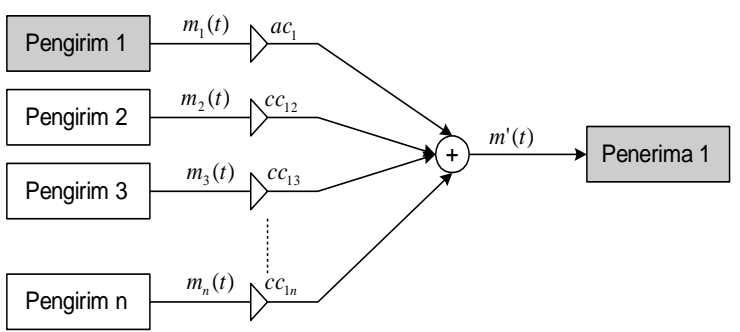

Gambar 13. Model MAI

Tabel 4 memuat perbedaan 10 (sepuluh) pasangan nilai kondisi awal $\left(x_{0}, y_{0}, z_{0}\right)$ untuk 10 (sepuluh) buah sinyal chaos yang dipergunakan sebagai kode penebar pada percobaan model (CD) ${ }^{2}$ MA untuk 10 (sepuluh) pengguna, dengan 1 (satu) sinyal diinginkan dan 9 (sembilan) sinyal lainnya sebagai MAI. Tabel 5 memuat nilai-nilai kros-korelasi ternormalisasi antar-sepuluh kode penebar tersebut.

Tabel 4. Kondisi Awal untuk 10 Jenis Sinyal Chaos

\begin{tabular}{|c|c|c|c|}
\hline \multirow{2}{*}{ Spreader } & \multicolumn{3}{|c|}{ Initial condition } \\
\cline { 2 - 4 } & $\boldsymbol{x}_{\mathbf{0}}$ & $\boldsymbol{y}_{\mathbf{0}}$ & $\boldsymbol{z}_{\mathbf{0}}$ \\
\hline Spreader 1 (Sp1) & 0.1 & 0.1 & 0.1 \\
\hline Spreader 2 (Sp2) & 5 & 5 & 5.45351 \\
\hline Spreader 3 (Sp3) & 2 & 2 & 2.2965435 \\
\hline Spreader 4 (Sp4) & 3 & 3 & 3.2965435 \\
\hline Spreader 5 (Sp5) & 7.57635 & 8 & 2 \\
\hline Spreader 6 (Sp6) & 6.53456 & 3 & 2 \\
\hline Spreader 7 (Sp7) & 1.53456 & 3 & 1 \\
\hline Spreader 8 (Sp8) & 0.53456 & 6 & 9 \\
\hline Spreader 9 (Sp9) & 1 & 9.674 & 2.3423 \\
\hline Spreader 10 (Sp10) & 5 & 2.674 & 6.3423 \\
\hline
\end{tabular}

Tabel.5. Nilai-Nilai Kros-Korelasi Ternormalisasi untuk 10 Jenis Sinyal Chaos yang Berbeda

\begin{tabular}{|c|c|c|c|c|c|c|c|c|c|c|}
\hline & Sp1 & Sp2 & Sp3 & Sp4 & Sp5 & Sp6 & Sp7 & Sp8 & Sp9 & Sp10 \\
\hline Sp1 & 1 & 0.0553 & 0.0156 & 0.0096 & 0.0705 & 0.0106 & 0.0035 & 0.0647 & 0.0281 & 0.0488 \\
\hline Sp2 & 0.0533 & 1 & 0.0032 & 0.2858 & 0.2894 & 0.0919 & 0.3638 & 0.0304 & 0.2594 & 0.3690 \\
\hline Sp3 & 0.0151 & 0.0033 & 1 & 0.2848 & 0.0538 & 0.0923 & 0.4795 & 0.3015 & 0.2671 & 0.1984 \\
\hline Sp4 & 0.0092 & 0.2848 & 0.2825 & 1 & 0.1675 & 0.0102 & 0.0755 & 0.1746 & 0.3698 & 0.3615 \\
\hline Sp5 & 0.0669 & 0.2844 & 0.0526 & 0.1651 & 1 & 0.0768 & 0.1592 & 0.1056 & 0.3460 & 0.1833 \\
\hline Sp6 & 0.0099 & 0.0894 & 0.0032 & 0.0090 & 0.0761 & 1 & 0.2392 & 0.2220 & 0.3938 & 0.4122 \\
\hline Sp7 & 0.0034 & 0.3663 & 0.4805 & 0.0762 & 0.1632 & 0.2476 & 1 & 0.2089 & 0.3898 & 0.1943 \\
\hline Sp8 & 0.0629 & 0.0307 & 0.3025 & 0.1766 & 0.1083 & 0.2301 & 0.2092 & 1 & 0.0520 & 0.2127 \\
\hline Sp9 & 0.0272 & 0.2605 & 0.2671 & 0.3725 & 0.3535 & 0.4064 & 0.3886 & 0.0517 & 1 & 0.2153 \\
\hline Sp10 & 0.0475 & 0.3728 & 0.1997 & 0.3664 & 0.1884 & 0.4282 & 0.1949 & 0.2132 & 0.2166 & 1 \\
\hline
\end{tabular}

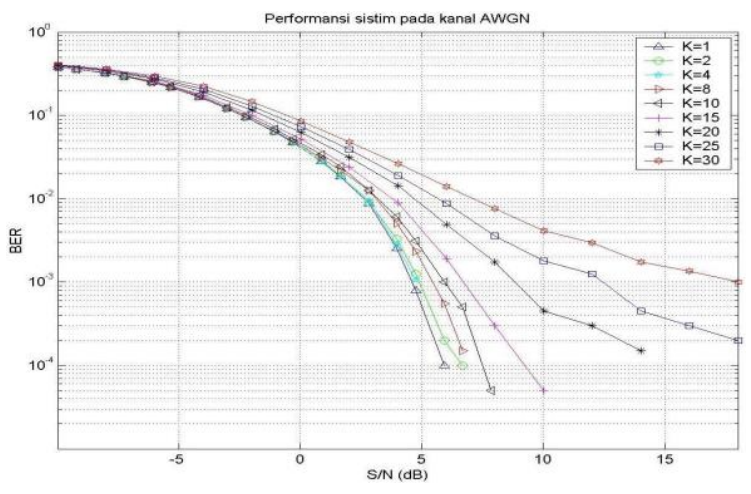

Gambar 14. Kinerja (CD) ${ }^{2}$ MA pada Kanal AWGN

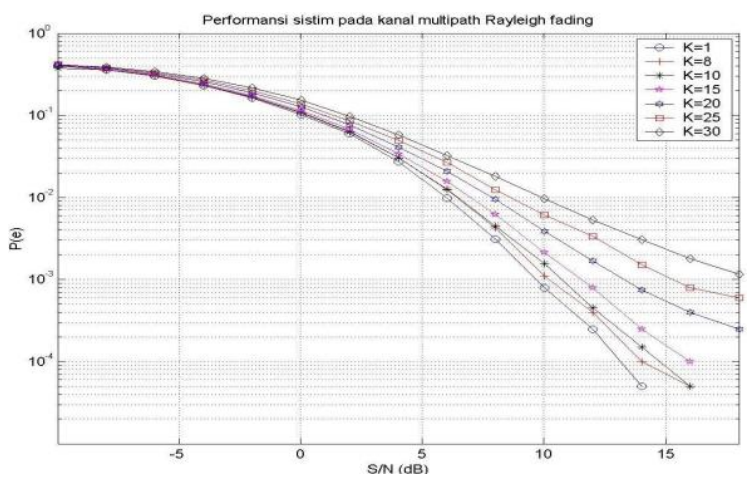

Gambar 15. Kinerja (CD) ${ }^{2}$ MA pada Kanal Rayleigh-1

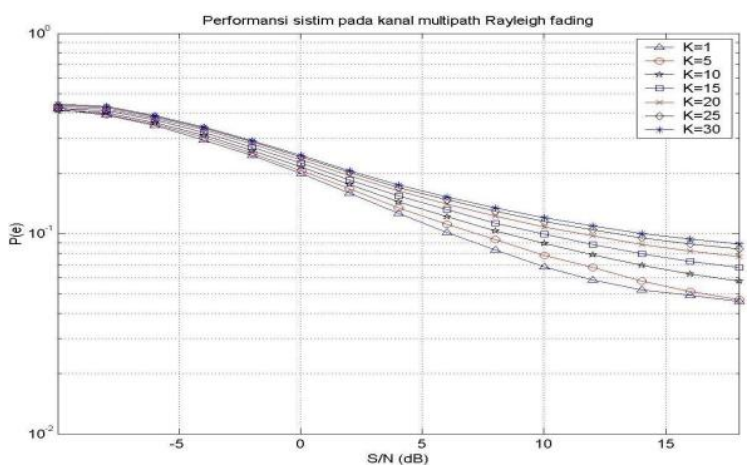

Gambar 16. Kinerja (CD) ${ }^{2}$ MA pada Kanal Rayleigh-2

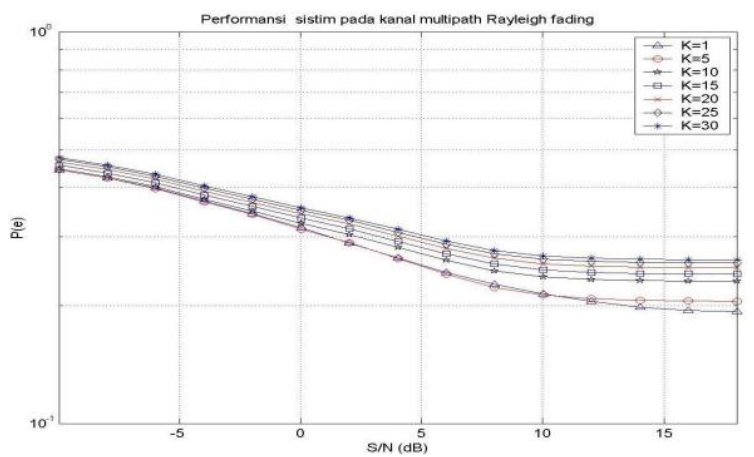

Gambar 17. Kinerja (CD) ${ }^{2}$ MA pada Kanal Rayleigh-3

\subsection{Kinerja Sistem $(\mathrm{CD})^{2}$ MA di Berbagai Kanal}

Pada Gambar 14 s. d. 17 diperlihatkan grafikgrafik kinerja sistem $(\mathrm{CD})^{2} \mathrm{MA}$ pada setiap model kanal yang digunakan, dengan diberikan efek MAI 
untuk jumlah sinyal $(\mathrm{CD})^{2}$ MA sebanyak $K=[1,30]$ pengguna. Gambar 2 memperlihatkan bahwa pada model kanal Rayleigh-2 setiap penambahan sebanyak 5 pengguna akan memberikan kenaikan nilai $S / N$ rata-rata sekitar $1 \mathrm{~dB}$, jika dievaluasi pada nilai BER $10^{-1}$.

Hal lain yang sebenarnya juga menentukan kinerja sistem $(\mathrm{CD})^{2} \mathrm{MA}$, namun tidak dipertimbangan sebagai variabel penelitian ini, adalah Processing Gain yang didefinisikan sebagai perbandingan antara data rate setelah spreading terhadap data rate sebelum spreading, atau dapat dihitung dari perbandingan anata chip rate $R_{c}$ terhadap data rate $R_{d}$ :

$$
P G(d B)=10 \log \left(\frac{R_{c}}{R_{d}}\right)=10 \log (N)[d B]
$$

dengan $R_{c}=N \times R_{d}$.

\section{Kesimpulan}

1. Pada BER $10^{-3}$, penggunakan modulasi QCSK pada sistem (CD) ${ }^{2} \mathrm{MA}$ memberikan perbaikan nilai $S / N$ sebesar 3,8 dB dibandingkan terhadap penggunaan modulasi $\operatorname{VMSK}(-)$, sedangkan apabila dibandingkan terhadap penggunaan modulasi VMSK(+) akan memberikan perbaikan nilai $S / N$ sebesar $6 \mathrm{~dB}$. Jika dibandingkan dengan BPSK, QCSK akan memberikan perbaikan $S / N$ sebesar 8,4 dB. Jadi perbaikan oleh penggunakan modulasi QCSK dapat dipandang signifikan.

2. Untuk BER $10^{-3}$ pada kanal AWGN, untuk jumlah pengguna kurang dari 15, setiap penambahan satu pengguna menyebabkan pengurangan nilai rata-rata $S / N$ sebesar $0,2 \mathrm{~dB}$. Sedangkan untuk jumlah pengguna kurang dari 15, setiap penambahan satu pengguna menyebabkan pengurangan nilai rata-rata $S / N$ sebesar $0,7 \mathrm{~dB}$.

3. Pemodelan Kanal Rayleigh fading dengan delay spread $0,3 \mu$ s akan mengakibatkan sinyal yang ditransmisikan mengalami frequency selective fading yang mengakibatkan terjadinya ISI, dan menyebabkan kinerja sistem menurun drastis, sehingga dapat disarankan untuk menambahkan suatu sistem Pengkodean FEC (Forward Error Correcting) untuk mengurangi error.

\section{Daftar Pustaka}

[1] Fikry, A., 2002. Perancangan dan Simulasi Sistem Chaotic Digital Code Divission Multiple Access. STT Telkom Bandung.

[2] Freeman, Roger L., 1974, Telecommunication Transmission Handbook, Wiley International Publication, London.

[3] Galias, Z and G. M. Maggio, Quadrature Chaos Shift Keying.
[4] Johansson, M., The Hilbert Transform, Vaxjo University.

[5] Kennedy, Peter Michael, 1998, Application of Chaos in Communication.

[6] Kocarev, L., K.S Halle, K. Eckert, L. O. Chua, and U. Parliz. Experimental Demontration of Secure Communication via Chaotic Synchronization, International Journal Biffuraction Chaos. Vol. 2, pp. 709-713, 1992.

[7] Kolumban, G., B. Vizvari, W. Schwarz, and A. Able, Differential Chaos Sift Keying: A Robust Coding for Chaos Communication, Proceeding $4^{\text {th }}$ International Specialist Workshop on NonLinear Dynamic of Electronic Sistem (NDES '96), Seville, Spain, June 1996, pp 87-92.

[8] Lau, F. C. M., M. M. Yip, C. K. Tse, and S. F. Hau, A Multiple-Access Technique for Differential Chaos-Shift Keying-1: Fundamental Theory and Application. IEEE Trans. on Circuit and System, Vol. 49, No. 1, January 2002.

[9] Rappaport T. S., 1996, Wireless Communication. Prantice Hall, New Jersey.

[10] Sardar, Z., dan I. Abrams, 1998, Mengenal Chaos: for Beginners, Mizan Media Utama.

[11] Schweizer, J., and M. P. Kennedy, Predictive Poincare Control Modulation: A New Methode for Modulating Digital Information onto a Chaotic Carrier Signal, Proceeding Irish DSP and Control Colloquium, Dublin, Ireland, 1994, pp 125-132.

[12] Sklar, Bernard, 1988, Digital Communication, Prantice Hall, New Jersey. 